Am J Obstet Gynecol 126:956

2. Belik J, Wagerle LC, Tzimas M, Egler JM, Delivoria-Papadopoulos M 1983 Cerebral blood flow and metabolism following pancuronium paralysis in newborn lambs. Pediatr Res 17:146A (abstr)

3. Berne RM, Winn HR, Rubio R 1981 The local regulation of cerebral blood flow. Prog Cardiovasc Dis 24:243

4. Brann AW Jr, Meyers RE 1975 Central nervous system findings in the newborn monkey following severe in utero partial asphyxia. Neurology 25:327

5. Bucciarelli RL, Eitzman DV 1979 Cerebral blood flow during acute acidosis in perinatal goats. Pediatr Res 13:178

6. Dobbing J, Sands J 1979 Comparative aspects of the brain growth spurt. Early Hum Dev 3:79

7. Fox WW 1982 Arterial blood gas evaluation and mechanical ventilation in the management of persistent pulmonary hypertension of the neonate. In: Peckham GJ, Heymann MA (eds) Cardiovascular Sequelae of Asphyxia in the Newborn, Report of the 83rd Meeting of Ross Laboratories, Ross Laboratories, Columbus, $\mathrm{OH}, \mathrm{p} 102$

8. Gilmour DG, Douglas IHS, Aithenhead AR, Hothersall AP, Horton PW, Ledingham IM 1980 Colon blood flow in the dog: effect of changes in arterial carbon dioxide tension. Cardiovasc Res 14:111

9. Häggendal E, Johnasson B 1965 Effects of arterial carbon dioxide tension and oxygen saturation on cerebral blood autoregulation in dogs. Acta Physio Scand Suppl 258:27

10. Harper AM, Glass HI 1965 Effect of alterations in the arterial carbon dioxide tension on the blood flow through the cerebral cortex at normal and low arterial blood pressures. J Neurol Neurosurg Psychiat 28:449

11. Hemmingsen R, Barry DI, Hertz MM 1979 Cerebrovascular effects of central depressants: a study of nitrous oxide, halothane, pentobarbital and ethanol during normocapnia and hypercapnia in the rat. Acta Pharmacol Toxicol 45:287

12. Hernández MJ, Brennan RW, Vannucci RC, Bowman GS 1978 Cerebral blood flow and oxygen consumption in the newborn dog. Am $\mathrm{J}$ Physiol 234:R209

13. Heymann MA, Payne BD, Hoffman JI, Rudolph AM 1977 Blood flow measurements with radionuclide-labeled particles. Prog Cardiovasc Dis 20:55

14. Iwabuchi T, Kutsuzawa T, Kyuhei K, Nakamura T 1973 Effects of blood gases on the pressure-flow relationships in canine cerebral circulation. Stroke 4:65

15. Laptook AR, Stonestreet BS, Oh W 1983 Brain blood flow and $\mathrm{O}_{2}$ delivery during hemorrhagic hypotension in the piglet. Pediatr Res 17:77

16. Laptook AR, Stonestreet BS, Oh W 1982 The effect of different rates of plasmanate infusions on brain blood flow after asphyxia in newborn piglets. J Pediatr 100:791

17. Larrieu AJ, Newman GE, Syracuse DC, McClenathan JH, Guadini VA,
Michaelis $\mathrm{LL} 1978$ The effects of arterial $\mathrm{CO}_{2}$ tension on regional myocardial and renal blood flow: an experimental study. J Surg Res 25:312

18. Leahy FAN Cates D, MacCallum M, Rigatto $\mathrm{H} 1980$ Effect of $\mathrm{CO}_{2}$ and $100 \%$ $\mathrm{O}_{2}$ on cerebral blood flow in preterm infants. $\mathrm{J}$ Appl Physiol 48:468

19. Norman J, Macintyre J, Shearer JR, Craigen IM, Smith G 1970 Effect of carbon dioxide on renal blood flow. Am J Physiol 219:672

20. Nowicki PT Stonestreet BS, Hansen NB, Yao AC, Oh W 1983 Gastrointestinal blood flow and oxygen in awake newborn piglets: the effect of feeding. Am J Physiol 245:G697

21. Paulson OB, Olesen J, Christensen MS 1972 Restoration of auto-regulation of cerebral blood flow by hypocapnia. Neurology 22:286

22. Peckham GJ, Fox WW 1978 Physiological factors affecting pulmonary artery pressure in infants with persistent pulmonary hypertension. J Pediatr 93:1005

23. Pon WG, Haupt KA 1978 The Biology of the pig. Cornell University Press, Ithaca, p. 99

24. Purves MJ, James IM 1969 Observations on the control of cerebral blood flow in the sheep fetus and newborn lamb. Circ Res 25:651

25. Rahilly PM 1980 Effects of $2 \%$ carbon dioxide, $0.5 \%$ carbon dioxide and $100 \%$ oxygen on cranial blood flow on the human neonate. Pediatrics 66:685

26. Reivich M 1964 Arterial $\mathrm{pCO}_{2}$ and cerebral hemodynamics. Am J Physio 206:25

27. Reivich M, Brann AW Jr, Shapiro H, Rawson J, Sano N 1972 Reactivity of cerebral vessels to $\mathrm{CO}_{2}$ in the newborn rhesus monkey. Eur Neurol 6:132

28. Rosenberg AA, Jones DM Jr, Traystman RJ, Simmons MA, Molteni RA 1982 Response of cerebral blood flow to changes in $\mathrm{pCO}_{2}$ in fetal, newborn and adult sheep. Am J Physiol 242:H862

29. Shapiro HM, Greenberg JH, Van Horn Haughton K, Reivich M 1980 Heterogeniety of local cerebral blood-flow- $\mathrm{PaCO}_{2}$ sensitivity in neonatal dogs. $\mathrm{J}$ Appl Physiol 49:113

30. Stoyka WW, Schutz H 1974 Cerebral response to hypocapnia in normal and brain-injured dogs. Can Anaesth Soc J 21:205

31. Volpe JJ 1981 Neurology of the newborn. In: Schaffer AJ, Markowitz M (eds) Major Problems in Clinical Pediatrics, Vol 22. WB Saunders Company, Philadelphia, p 262

32. Volpe JJ 1976 Perinatal hypoxic-ischemic brain injury. Pediatr Clin N Am 23:383

33. Wagerle LC, Belik J, Jumar SP, Tzimas M, Delivoria-Papadopoulous M 1983 Cerebral oxygenation during acute reductions in plasma $\mathrm{pH}$ in newborn piglets. Pediatr Res 17:340A (abstr)

34. Wootton R, Flecknell PA, John M 1982 Accurate measurement of cerebral metabolism in the conscious, unrestrained neonatal piglet. I. Blood flow. Biol Neonate 41:209

\title{
Muscarinic Cholinergic Receptors in Developing Rat Lung
}

\author{
JEFFREY A. WHITSETT AND BRYAN HOLLINGER \\ Department of Pediatrics, University of Cincinnati College of Medicine, Cincinnati Ohio 45267
}

\begin{abstract}
Muscarinic cholinergic receptors were identified and partially characterized in crude membrane fractions of rat lung and trachea from day 17 of gestation to adulthood using (-)- $\left[{ }^{3} \mathrm{H}\right]$ quinuclidinyl benzilate (QNB). $(-)-\left[{ }^{3} \mathrm{H}\right] \mathrm{QNB}$ binding to rat lung membrane was characteristic of muscarinic cholinergic receptor sites. Binding
\end{abstract}

Received September 26, 1983; accepted March 33, 1984.

Correspondence may be addressed to Jeffrey A. Whitsett, M.D., Newborn Division. Department of Pediatrics, University of Cincinnati College of Medicine, Room 6210. Medical Sciences Building, M.L. 541, 231 Bethesda Avenue, Cincinnati. OH 45267.

This work was supported in part by Research Center Development Award HL 10124 from the National Institutes of Health and HL 28623 and HD 11725, and from the Children's Hospital Research Foundation, Cincinnati, OH. An abstract of this work was presented at a meeting of the Society for Pediatric Research, Washington. D. C.. May 1983. capacity of muscarinic receptors sites was relatively low in rat lung compared to that in other tissues. The number of (-) $-\left[^{3} \mathrm{H}\right] \mathrm{QNB}-$ binding sites (binding capacity) decreased progressively and significantly from $79 \pm 8 \mathrm{fmol} \cdot \mathrm{mg}^{-1}$ protein on days 17-18 of gestation to $21 \pm 3 \mathrm{fmol} \cdot \mathrm{mg}^{-1}$ mean \pm SEM on days $21-22$ of gestation, $p<0.01$. Binding capacity did not vary thereafter from birth to adulthood. Affinity of (-)-[ $\left.{ }^{3} \mathrm{H}\right] \mathrm{QNB}$ binding for lung membranes did not change with age ( $K_{D}$ approximately $\left.70 \mathrm{pM}\right) .(-)-\left[^{3} \mathrm{H}\right]$ QNB-binding sites were significantly higher in membrane preparations of trachea or tracheal-bronchial tissue than in lung parenchyma from both the adult and newborn rats. $\left.(-)-{ }^{3} \mathrm{H}\right] \mathrm{QNB}$ binding was undetectable in crude membrane preparations of cultured purified type II epithelial cells isolated from the adult rat lung. 
Muscarinic cholinergic receptor sites are present in rat lung as early as day 17 of gestation. Since preparations of proximal portions of the lung are relatively enriched in (-) $-\left[{ }^{3} \mathrm{H} \mid \mathrm{QNB}\right.$ binding compared to more peripheral portions of the lung, ontogenic decreases in $(-)-\left[{ }^{3} \mathrm{H}\right] \mathrm{QNB}$ binding may result from the higher contribution of trachealbronchial tissue compared to alveolar tissue in the preparations of early fetal lung, rather than to a specific regulation of muscarinic receptor sites. (Pediatr Res 18:11361140, 1984)

\section{Abbreviations}

QNB, quinuclidinyl benzilate

EGTA, ethylene glycol bis( $\beta$-aminoethyl ether)- $N, N$, $N^{\prime}, N^{\prime}$-tetraacetic acid

Cholinergic stimulation of pulmonary tissue alters smooth muscle tone, mucous secretion in the tracheal-bronchial tree, and surfactant secretion $(1,7,8,17)$. These effects are presumably mediated by the release of acetylcholine from muscarinic nerve endings and the subsequent activation of pulmonary muscarinic cholinergic receptors. Neural and humoral regulation of pulmonary function is of vital importance to perinatal respiratory adaptation, and dependent in part upon the presence of neurohormonal receptors on their target cells. Developmental aspects of $\alpha$-and $\beta$-adrenergic receptors have been recently demonstrated in pulmonary tissues, both $\alpha_{1}$ - and $\beta$-adrenergic receptor concentrations increasing dramatically during perinatal development in the rat lung $(10,20-22)$. Ontogenic aspects of muscarinic influences on lung function are less well defined. In the rat, acetylcholinesterase-positive nerve endings have been identified in paratracheal tissue as early as 13 days gestation and in the lung at birth $(9,14)$. Their density increased during the perinatal period, primarily along bronchi and major blood vessels. Acetylcholinesterase-positive cells were not present in peripheral alveolar tissue in this species $(9,14)$. Cholinergic agonists increased surfactant secretion in the perfused, purified rat lung but are not effective in isolated type II epithelial cells, supporting the premise that acetylcholine exerts its action in the type II epithelial cell by indirect mechanisms (3). Muscarinic receptor sites were recently identified in canine and bovine tracheal smooth muscle by direct binding studies using $(-)-\left[{ }^{3} \mathrm{H}\right] \mathrm{QNB}(5,16)$. Binding capacity was significantly higher in tracheal preparations than in bovine lung parenchyma (5). Ontogenic aspects of muscarinic receptors in pulmonary tissues have not been previously determined. In the present study, we describe muscarinic receptors in rat lung and tracheal-bronchial tissue during perinatal development using $(-)$ $\left[{ }^{3} \mathrm{H}\right] \mathrm{QNB}$, a potent muscarinic antagonist. Muscarinic-cholinergic receptors were also determined in membrane preparations of fetal and adult rabbit lung.

\section{MATERIALS AND METHODS}

Membrane preparations of whole lung homogenates were prepared from fetuses and pups obtained from time-dated SpragueDawley rats purchased from Charles River, Inc. Rabbit lung (New Zealand albino) was obtained from fetal (day 25) and adult animals and membranes were prepared as described for the rat. Dams (rat) were kept on 12-h light-dark cycles and routinely delivered at 22 days of gestation. Dams were sacrificed by cervical dislocation. The fetuses or pups were weighed and the lungs were carefully dissected from hilar tissues and placed in iced $250 \mathrm{mM}$ sucrose, $10 \mathrm{mM}$ Tris- $\mathrm{HCl}$ (pH 7.2), $1 \mathrm{mM}$ EGTA (STE buffer). Tracheal and proximal bronchial tissue (hilar tissue) were obtained from adult and newborn rats. Nontracheal tissue was carefully dissected from trachea and bronchi by direct visualization. Tissue was washed in the same iced buffer and homogenized in 9 volumes of STE by three 5-s bursts at high setting with a
Tekmar Tissuemizer (Cincinnati, OH). The homogenate was filtered through four layers of gauze and centrifuged at 3,000 $\times$ $g$ for $5 \mathrm{~min}$ at $4^{\circ} \mathrm{C}$. The resulting supernatant was centrifuged at $40,000 \times g$ for $30 \mathrm{~min}$. The resulting pellet was resuspended in iced buffer and centrifuged again at $40,000 \times g$ for $30 \mathrm{~min}$. This final crude membrane preparation was frozen in dry ice-acetone and stored at $-70^{\circ} \mathrm{C}(-)-\left[{ }^{3} \mathrm{H}\right] \mathrm{QNB}$ binding to these preparations was not altered during storage for up to 6 months. Prenatal and newborn preparations consisted of lungs pooled from entire litters. Postnatal samples consisted of samples of from two to four rats while adult samples were compared from individual animals. Protein concentrations in the membranes were determined by the method of Lowry using bovine serum albumin as standard (13).

Type II cell preparation. Type II epithelial cells were isolated from 200-250-g male Sprague-Dawley rats as described by Brown and Longmore (3). Cells from four rats were plated for 16 hours and adherent cells separated from the culture dishes in STE buffer. Crude membranes were prepared as above and diluted to $1-2 \mathrm{mg} / \mathrm{ml}$ in STE and used in the binding assay. These cells are generally $95 \%$ viable cells as assessed by trypan blue exclusion and 90\% type II cells as assessed by (phosphine $3 \mathrm{R}$ staining and electron microscopy of sample preparations). In our preparations, $\beta$-adrenergic agents increase the release of $\left[{ }^{3} \mathrm{H}\right]$ phosphatidylcholine from type II cells in association with increasing cAMP levels. Crude membranes from these cells also contain $\beta$-adrenergic receptors defined with $(-)-\left[{ }^{3} \mathrm{H}\right]$ dihydroalprenolol.

(-)- $\left[^{3} H\right] Q N B$-binding assay. (-)-[ $\left[{ }^{3} \mathrm{H}\right] \mathrm{Quinuclidinyl}$ benzilate (40.2 $\mathrm{Ci} / \mathrm{mmol}$ ) was obtained from New England Nuclear, Boston, MA. Stock solutions were diluted in distilled water and stored at $-30^{\circ} \mathrm{C}$ prior to use. (-) $-\left[{ }^{3} \mathrm{H}\right] \mathrm{QNB}$ binding was determined in an assay similar to that described by Hardin et al. (12). Incubations were performed in a $1-\mathrm{ml}$ assay volume containing $10 \mathrm{mM}$ magnesium chloride, $50 \mathrm{mM}$ Tris-HCl (pH 7.2), and $50-100 \mu \mathrm{g}$ of lung membrane. Tubes were incubated at $37^{\circ} \mathrm{C}$ for $90 \mathrm{~min}$ in a shaking water bath. The reaction was terminated by filtration on Whatman GFC filters. The assay tube was washed with $4 \mathrm{ml}$ of incubation buffer onto the filter and the tube was rinsed twice with $4 \mathrm{ml}$ of the same buffer at $37^{\circ} \mathrm{C}$. Filters were dried and placed in $7 \mathrm{ml}$ of scintillation fluid. Nonspecific binding was determined in the presence of $10^{-6} \mathrm{M}$ atropine. All incubations were performed in duplicate or triplicate. Specific binding was determined by subtracting nonspecific binding (in the presence or absence of $10^{-6} \mathrm{M}$ atropine) from total binding. Receptor number and affinity were determined from saturation experiments using increasing concentrations of $(-)-\left[{ }^{3} \mathrm{H}\right] \mathrm{QNB}$ (10-500 pM) and analyzed by the method of Scatchard (19). Preliminary experiments demonstrated that nonspecific binding increased in a linear fashion with increasing $(-)-\left[{ }^{3} \mathrm{H}\right] \mathrm{QNB}$ concentration. Therefore, in some experiments specific binding was calculated by subtracting binding values obtained from a computer-fit regression line generated from "nonspecific" values obtained from two or three ligand concentrations within the range of the assay.

Competition experiments were determined in the presence of $100-200 \mathrm{pM}(-)-\left[{ }^{3} \mathrm{H}\right] \mathrm{QNB}$ and increasing concentrations of the cholinergic agents. Affinity and slope of the inhibition curves were obtained using the program Direct Fit (11), Significance of differences in binding capacity at various ages was determined by a one-way analysis of variance. Atropine, oxotremorine, methacholine, $d$-tubocurarine, acetylcholine, carbamylcholine, and guanosine triphosphate were obtained from Sigma Chemical Co., St. Louis, MO. Gpp(NH)p was purchased from ICN, Irvin, CA.

\section{RESULTS}

(-)- $\left[{ }^{3} \mathrm{H}\right] \mathrm{QNB}$ binding to particulate fractions of neonatal and adult rat lung membranes was time dependent and reversible. Nonspecific binding was less than $20 \%$ of total binding near saturation. Specific binding increased in relation to time (Fig. 1), reaching maximal binding within $90 \mathrm{~min}$ of incubation at lower 
ligand concentrations. Incubation time of $120 \mathrm{~min}$ and longer resulted in decreased binding. Specific binding increased in direct proportion to protein (40-200 $\mu \mathrm{g}$ ) (Fig. 2). Binding increased nonlinearly in relation to increasing concentrations of $(-)-\left[{ }^{3} \mathrm{H}\right]$ QNB (Fig. 3a). Scatchard analyses of these saturation curves were entirely linear in both fetal and adult samples, suggesting the presence of a single class of binding sites (Fig. $3 b$ ). Affinity of $(-)-\left[{ }^{3} \mathrm{H}\right] \mathrm{QNB}$ was approximately $70 \mathrm{pM}$ in both fetal and rat lung membranes and did not change during development. In contrast, binding capacity decreased in late gestation, from approximately $79 \pm 8.3 \mathrm{fmol} \cdot \mathrm{mg}^{-1}$ protein on days $17-18$ of gestation reaching adult levels of binding by 21-22 days of gestation, $21 \pm 3 \mathrm{fmol} \cdot \mathrm{mg}^{-1}$ protein. Binding capacity did not

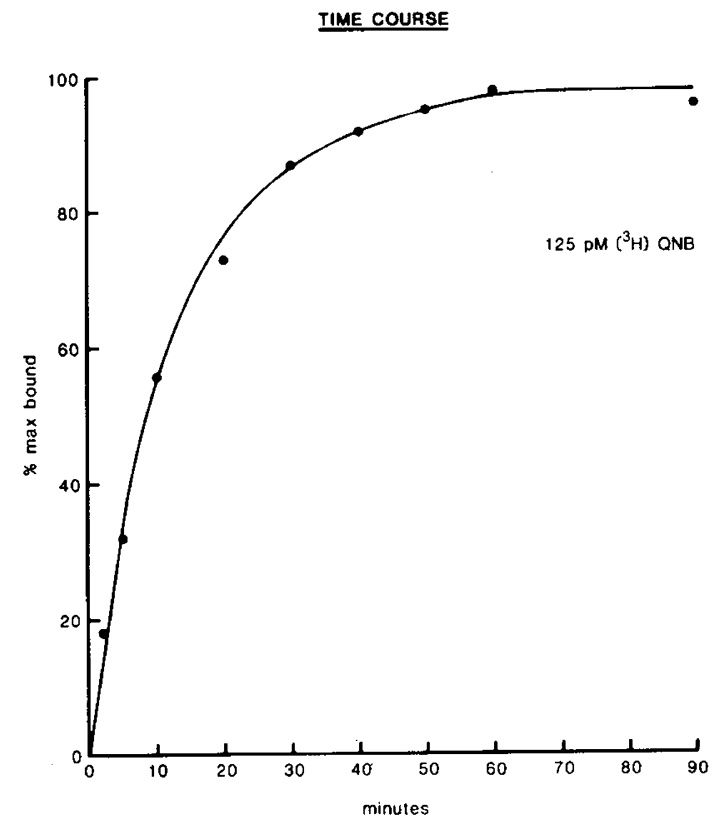

Fig. 1. Time course of specific (-)-[ $\left.{ }^{3} \mathrm{H}\right] \mathrm{QNB}$ binding to 19 -day fetal rat lung membranes. Lung membrane $(100 \mu \mathrm{g})$ was incubated in the presence of $125 \mathrm{pM}(-)-\left[{ }^{3} \mathrm{H}\right] \mathrm{QNB}$ in the presence or absence of $10^{-6}$ atropine as described in "Materials and Methods" for 1-90 min. Specific binding was determined in duplicate assays at each time point. change thereafter (determined on postnatal days $2,6,14$, and adulthood) (Table 1).

Specificity of the receptor site was assessed by competition experiments with (-)- $\left[{ }^{3} \mathrm{H}\right] \mathrm{QNB}$ and cholinergic agents (Table 2). Cholinergic antagonists inhibited specific ( -$)-\left[{ }^{3} \mathrm{H}\right] \mathrm{QNB}$ binding with characteristics of muscarinic cholinergic receptors, atropine being approximately 10,000 times more potent than $d$-tubocurarine. The slopes of inhibition curves for cholinergic antagonists

18-Day Fetal Rat Lung
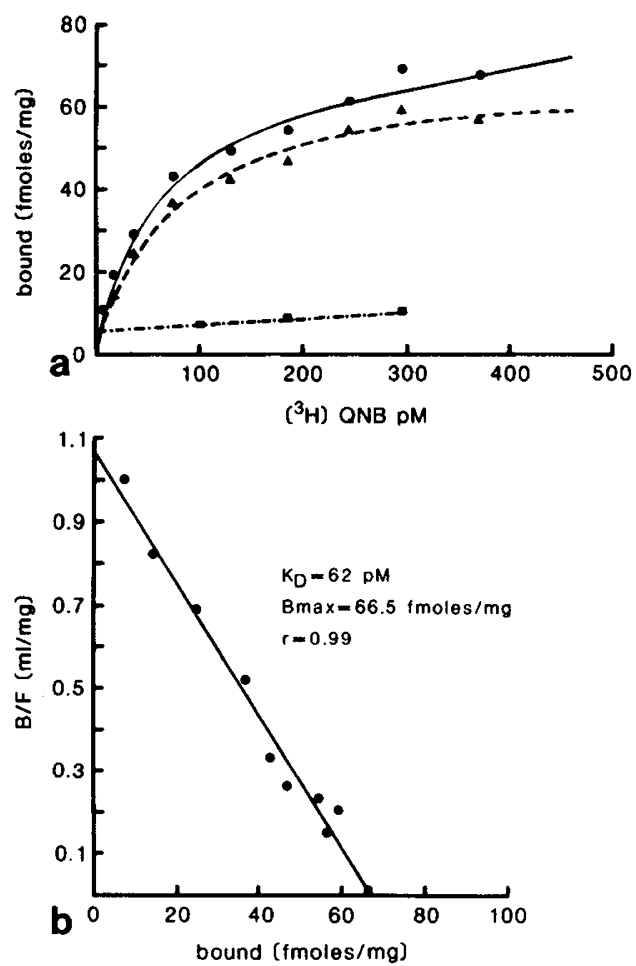

Fig. 3. Saturation experiment and Scatchard plot of (-) $\left[{ }^{3} \mathrm{H}\right] \mathrm{QNB}$ binding to lung membranes from day 18 of gestation. Specific and nonspecific (-)- $\left[{ }^{3} \mathrm{H}\right] \mathrm{QNB}$ binding was determined using approximately $100 \mu \mathrm{g}$ membrane protein and $10-500 \mathrm{pM}(-)-\left[{ }^{3} \mathrm{H}\right] \mathrm{QNB}$ as described in "Materials and Methods." Scatchard plot of the saturation data in $a$.

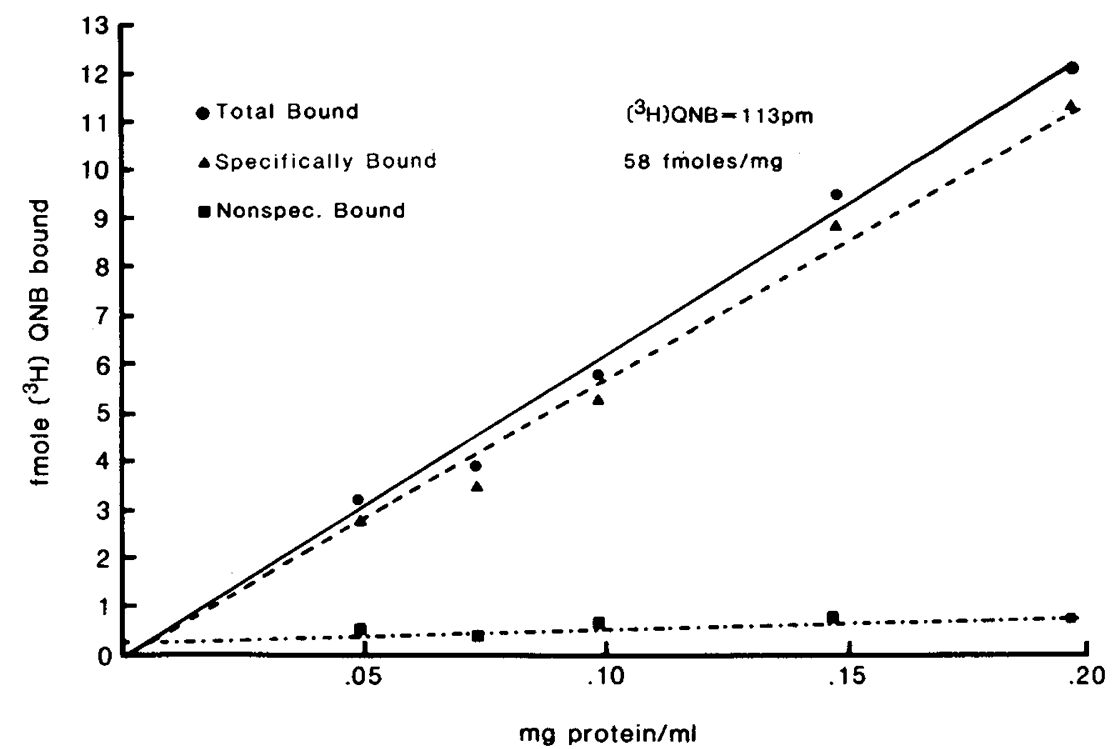

Fig. 2. Relationship between $(-)-\left[{ }^{3} \mathrm{H}\right] \mathrm{QNB}$ binding and membrane protein. Membrane $(0-200 \mu \mathrm{g})$ from a 19-day gestation fetal rat lung was incubated with (-)- $\left[{ }^{3} \mathrm{H}\right] \mathrm{QNB}$ in the presence and absence of $10^{-6} \mathrm{M}$ atropine for 90 minutes at $37^{\circ} \mathrm{C}$ as described in "Materials and Methods." Binding capacity in this preparation was $58 \mathrm{fmol} \cdot \mathrm{mg}^{-1}$ protein. 
Table 1. (-)- $\left[{ }^{3} H\right] Q N B$-binding capacity and affinity in crude lung and tracheal-bronchial membranes*

\begin{tabular}{llcc}
\hline & \multicolumn{2}{c}{$(-)-\left[{ }^{3} \mathrm{H}\right] \mathrm{QNB}-$ binding capacity } & $\frac{K_{D}}{(\mathrm{pM})}$ \\
\hline Fetal, days 17-18 & 4 & $79 \pm 8$ & $71 \pm 16$ \\
Fetal, day 19 & 3 & $49 \pm 10$ & $62 \pm 19$ \\
Fetal, days 21-22 & 5 & $21 \pm 3$ & $74 \pm 19$ \\
$\begin{array}{l}\text { Adult } \\
\text { Newborn tracheal-bron- }\end{array}$ & 4 & $20 \pm 3$ & $70 \pm 14$ \\
$\quad$ chial (hilar) mem- & & & 28 \\
$\quad$ bral & &
\end{tabular}

chial (hilar) mem-

branes

Adult tracheal-bronchial 5

$68 \pm 17$

$75 \pm 16$

* Binding capacity and affinity constant $\left(K_{D}\right)$ were determined in membrane preparation of lung or tracheal-bronchial tissue by saturation experiments as described in "Materials and Methods." Tracheal-bronchial tissue was dissected from other hilar tissue in adult samples under direct visualization. Tracheal-bronchial tissues from an entire litter of newborn pups were pooled and included other hilar tissue which could not be clearly dissected from the major bronchi. Values are mean \pm SEM of multiple preparations $(n)$. Statistical differences were determined by one-way analysis of variance. Age-related differences were significant at $p<0.001$. Binding to adult lung membranes were significantly less than to adult tracheal-bronchial membranes, $p=0.007$.

Table 2. Competition experiments with cholinergic agents and $(-)-\left[{ }^{3} H\right] Q N B$ with adult rat lung membranes*

\begin{tabular}{lll}
\hline \multicolumn{1}{c}{ Cholinergic agent } & \multicolumn{1}{c}{$K_{I}(\mathrm{M})$} & \multicolumn{1}{c}{ Slope } \\
\hline Atropine & $4.8 \pm 1.7 \times 10^{-9}$ & $0.86 \pm 0.1$ \\
Oxotremorine & $2.2 \pm 0.20 \times 10^{-7}$ & $0.53 \pm 0.06$ \\
Oxotremorine $(\mathrm{Gpp}(\mathrm{NH}) \mathrm{p})$ & $2.5 \pm 0.69 \times 10^{-7}$ & $0.46 \pm 0.05$ \\
Methacholine & $3.1 \pm 1.0 \times 10^{-6}$ & $0.54 \pm 0.004$ \\
Methacholine $(\mathrm{GTP})$ & $4.7 \pm 1.5 \times 10^{-6}$ & $0.54 \pm 0.08$ \\
Tubocurarine & $3.8 \pm 1.0 \times 10^{-5}$ & $0.84 \pm 0.1$ \\
Acetylcholine $(n=1)$ & $3.2 \times 10^{-6}$ & 0.52 \\
Carbamylcholine $(n=1)$ & $2.1 \times 10^{-6}$ & 0.48 \\
\hline
\end{tabular}

* Increasing concentrations of cholinergic agents $\left(10^{-11}-10^{-3} \mathrm{M}\right)$ were added to incubations with rat lung membrane and $100 \mathrm{pM}(-)-\left[{ }^{3} \mathrm{H}\right] \mathrm{QNB}$ as described in "Materials and Methods." The $K_{I}$ and slope of the inhibition curves were determined using the program Direct Fit. Values are mean $\pm \mathrm{SD}$ of three experiments with each agent except where indicated $n=1$. Gpp $(\mathrm{NH}) \mathrm{p}$ and GTP were added at $10 \mu \mathrm{M}$ where indicated.

were approximately 1.0 in the presence or absence of $10 \mu \mathrm{M}$ GTP (Fig. 4). Cholinergic agonists also inhibited (-)- $\left[{ }^{3} \mathrm{H}\right] \mathrm{QNB}$ binding in the order of potency oxotremorine $>$ methacholine $=$ acetylcholine $=$ methacholine $=$ carbamylcholine (Table 2 ). Slopes of inhibition of $(-)-\left[{ }^{3} \mathrm{H}\right] \mathrm{QNB}$ binding observed with the agonists were considerably less than 1 , ranging from $0.48-0.53$, Fig. 4). Addition of $10 \mu \mathrm{M}$ GTP or $10 \mu \mathrm{M} \mathrm{Gpp}(\mathrm{NH}) \mathrm{p}$ did not affect either the affinity or slope of competition of $(-)-\left[{ }^{3} \mathrm{H}\right] \mathrm{QNB}$ binding by either oxotremorine or methacholine (Table 2).

While the specific activity of lung $(-)-\left[{ }^{3} \mathrm{H}\right] \mathrm{QNB}$-binding sites decreased significantly in late gestation, it was unclear whether this related to specific regulation of muscarinic receptors in the target tissue or to changes in the growth and distribution of tracheal-bronchial as compared to alveolar tissues. The specific activity of $(-)-\left[{ }^{3} \mathrm{H}\right] \mathrm{QNB}$ binding to tracheal-bronchial tissue was therefore assessed in both neonatal and adult samples. $(-)-\left[{ }^{3} \mathrm{H}\right]$ QNB bound to tracheal membranes with characteristics identical to those observed in lung preparation. Specific activity was higher in adult tracheal-bronchial membranes, approximately $70 \mathrm{fmol}$. $\mathrm{mg}^{-1}$, than in adult rat lung membrane, $20 \mathrm{fmol} \cdot \mathrm{mg}^{-1}$. Likewise, $(-)-\left[{ }^{3} \mathrm{H}\right] \mathrm{QNB}$-binding activity was higher in tracheal-bronchial tissues than in whole membranes from the newborn rat lung. Dissection of adequate tracheal-bronchial tissue from prenatal samples was not feasible due to small tissue size. Thus, proximal

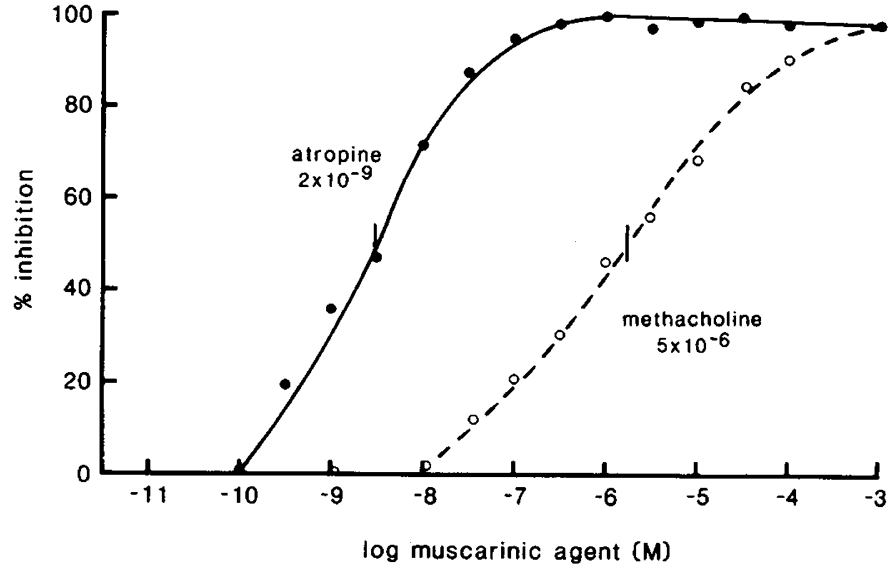

Fig. 4. Inhibition of $(-)-\left[{ }^{3} \mathrm{H}\right] \mathrm{QNB}$ binding by atropine and methacholine. Membrane $(100 \mu \mathrm{g})$ was incubated for $60 \mathrm{~min}$ at $37^{\circ} \mathrm{C}$ in the presence of $\left.100 \mathrm{pM}(-)-{ }^{3} \mathrm{H}\right] \mathrm{QNB}$ and increasing concentrations of atropine or methacholine. $K_{D}$ is indicated for each agent. The slope of the inhibition curve was 1.03 for atropine and 0.56 for methacholine. Neither GTP nor Gpp(NH)p (10 $\mu \mathrm{M})$ altered the slope.

airway tissues appear to contain significantly more muscarinic cholinergic receptor sites than parenchymal-alveolar tissue in rat lung. To further address specific cellular localization of $(-)-\left[{ }^{3} \mathrm{H}\right]$ QNB-binding sites in alveolar tissues, $(-)-\left[{ }^{3} \mathrm{H}\right] \mathrm{QNB}$ binding was assessed in membrane preparations of purified type II epithelial cells after isolation and tissue culture using the method of Brown and Longmore, as previously described $(3,23)$. Specific $(-)-\left[{ }^{3} \mathrm{H}\right]$ QNB binding could not be detected in membrane preparations of type II epithelial cells in multiple experiments. In contrast, membranes from these cells contained $\beta$-adrenergic receptors (demonstrated with $(-)-\left[{ }^{3} \mathrm{H}\right]$ dihydroalprenolol), increased intracellular CAMP concentrations and secreted phosphatidylcholine in response to $\beta$-adrenergic stimulation with terbutaline.

In order to test for possible species differences in muscarinic receptor activity, $(-)-\left[{ }^{3} \mathrm{H}\right] \mathrm{QNB}$ binding was assessed in fetal and adult rabbit lung by saturation experiments in membrane prepared as described in "Materials and Methods." $(-)-\left[{ }^{3} \mathrm{H}\right] \mathrm{QNB}-$ binding capacity was considerably higher in rabbit than in rat lung (148 $\pm 20 \mathrm{fmol} \cdot \mathrm{mg}^{-1}$ protein; $K_{D}=135 \pm 13 \mathrm{pM}$; mean \pm SEM; $n=5)$ and did not differ from that in fetal rabbit lung on day 25 of a 32 -day gestation, $\left(122 \pm 12 \mathrm{fmol} \cdot \mathrm{mg}^{-1}\right.$ protein; $K_{D}$ $=167 \pm 19 \mathrm{pM} ; n=4$ separate preparations).

\section{DISCUSSION}

The present study demonstrates muscarinic-cholinergic receptors in membrane preparations of rat lung and tracheal-bronchial tissue during perinatal development. Both rat lung and trachealbronchial tissues contained muscarinic-cholinergic receptor sites characteristic of those in other tissues, including canine tracheal smooth muscle $(5,16)$. In the rat, binding capacity for $(-)-\left[{ }^{3} \mathrm{H}\right]$ QNB decreased in late gestation. Specific activity of $(-)-\left[{ }^{3} \mathrm{H}\right]$ QNB binding in rabbit lung membranes was considerably higher than in those from rat and age-related differences were not detected between preparations of fetal (day 25 of gestation) and adult animals. Specific activity of $(-)-\left[{ }^{3} \mathrm{H}\right] \mathrm{QNB}$ binding was higher in tracheal-bronchial tissue than in more distal portions of the adult and newborn rat lung parenchyma. Crude membranes from purified rat type II epithelial cells did not contain detectable $(-)-\left[{ }^{3} \mathrm{H}\right] \mathrm{QNB}$-binding sites.

In the rat, characteristics of $\left.(-)-{ }^{3} \mathrm{H}\right] \mathrm{QNB}$ binding in these tissues were similar to those previously reported in tracheal smooth muscle, heart, and brain. However, binding capacity was relatively low in lung membrane compared to other tissues $(5,6$, 12 , 24). Affinity of $(-)-\left[{ }^{3} \mathrm{H}\right] \mathrm{QNB}$ for muscarinic-cholinergic receptors in both fetal and adult lung was estimated from saturation experiments and was similar to that previously described $(5,16$, 
$18,24)$. Binding appears to occur to a single class of binding sites and competition experiments with muscarinic-cholinergic agents demonstrated an order of potency characteristic of muscarinic, rather than nicotinic, receptor sites. The slope of inhibition of $(-)-\left[{ }^{3} \mathrm{H}\right] \mathrm{QNB}$ binding by antagonists was approximately 1 , consistent with interaction of a single class of receptor sites. In contrast, the slopes of competition experiments with cholinergic agonists were significantly less than 1 and were unaltered by the addition of GTP or its nonhydrolyzable analogue $\mathrm{Gpp}(\mathrm{NH}) \mathrm{p}$. Guanine nucleotide regulation of muscarinic receptor affinity has been previously demonstrated in both heart and brain (18, 24). Guanine nucleotide effects on bovine tracheal muscarinic receptors appear complex, altering both (-)- $\left[{ }^{3} \mathrm{H}\right] \mathrm{QNB}$ binding (antagonist) and agonist affinity; effects of guanine nucleotides were small and potentiated by $\mathrm{Mg}^{2+}(6)$. We are unable to identify changes in either affinity or slope of the inhibition of binding by agonists or antagonists in the presence of guanine nucleotide. This might be related to excessive GTP hydrolysis during the assay; however, agonist affinity was not significantly altered by $\mathrm{Gpp}(\mathrm{NH}) \mathrm{p}$, its nonhydrolyzable analogue.

Demonstration of increased muscarinic-cholinergic receptor sites in tracheal-bronchial tissue, as compared to lung parenchymal tissue, correlates well with the demonstration of acetylcholinesterase staining in histochemical studies of rat lung and trachea during development $(9,14,15)$. In those studies, acetylcholinesterase-positive nerves were identified as early as day 18 of gestation and were located primarily along tracheal and bronchial smooth muscle in the rat (9). Neuroepithelial bodies were also acetylcholinesterase positive in the rat lung (14). Recent studies with bovine lung and trachea support this distribution, $(-)-\left[{ }^{3} \mathrm{H}\right] \mathrm{QNB}$ binding being much greater in bovine tracheal as compared to parenchymal membrane preparations (5). Recent autoradiographic studies of muscarinic receptors in ferret lung demonstrated $(-)-\left[{ }^{3} \mathrm{H}\right] \mathrm{QNB}$ binding primarily in trachea, cartilagenous airways, and submucosal glands and lacking in alveolar structures (2). The apparent lack of muscarinic-cholinergic receptor sites in type II epithelial cells presently described supports previous studies documenting the absence of surfactant secretion after cholinergic stimulation in isolated type II cells (3). The observation that pilocarpine-induced surfactant secretion in the perfused rat lung was blocked by treatment with propanolol supports the hypothesis that cholinergic stimulation of surfactant release is mediated by activation of the $\beta$-adrenergic system rather than by direct cholinergic stimulation of the type II epithelial cells (3).

The ontogenic decrease in muscarinic cholinergic receptor sites in developing rat lung was not observed in rabbit lung (day 25 of gestation and adult) and contrasts sharply with the increases in $\alpha_{1}$ - and $\beta$-adrenergic receptor sites which occur in both rat and rabbit lung during perinatal development. $\beta$-Adrenergic receptor sites increase during the perinatal period in the rat and rabbit lung and these increases are apparently mediated by both corticosteroids (prenatally) and thyroxine (postnally) in the developing lung $(4,10,20-22)$. There is evidence that developmental changes in acetylcholinesterase-positive pulmonary cells are also hormonally regulated, being enhanced by thyroxine in vitro (15). While it is possible that the ontogenic decreases in cholinergic receptors in developing rat lung occur on individual pulmonary cells, our data are compatible with the concept that muscarinic receptors are located primarily in the tracheal-bronchial tree rather than in the parenchymal (alveolar) components of the lung. Growth of the trachea and bronchi of the rat lung proceed much more rapidly than alveolar components during fetal life, the latter proliferating during the neonatal and postnatal periods. Thus, in fetal preparations from 17-18 days of gestation, the greater contribution of bronchial or other hilar tissues to lung membrane preparations may account for their increased (-)$\left[{ }^{3} \mathrm{H}\right] \mathrm{QNB}-$ binding capacity compared to samples from older animals.

\section{REFERENCES}

1. Abdellatif MM, Hollingsworth M 1977 The in vitro and in vivo effects of oxotremorine on phosphatidylcholine content of washes of neonatal rabbit lungs. Br J Pharmacol 61:502

2. Barnes P, Nadel JA, Roberts JM, Basbaum CB 1983 Muscarinic receptors in lung and trachea: autoradiographic localization using $\left[{ }^{3} \mathrm{H}\right]$ quinuclidinyl benzilate. Eur J Pharmacol 86:103

3. Brown LA, Longmore WJ 1981 Adrenergic and cholinergic regulation of lung surfactant secretion in the isolated perfused rat lung and in alveolar type II cells in culture. J Biol Chem 256:66

4. Cheng J, Goldfein A, Ballard PL, Roberts JM 1980 Glucocorticoids increase pulmonary $\beta$-adrenergic receptors in fetal rabbit. Endocrinology 107:1646

5. Cheng JB, Townley RG 1982 Comparison of muscarinic and beta-adrenergic receptors between bovine peripheral lung and tracheal smooth muscle: a striking difference in receptor concentration. Life Sci 30:2079

6. Cheng JB, Townley RG 1983 GTP increases airway muscarinic antagonist binding sites. an effect regulated by $\mathrm{Mg}$. Eur J Pharmacol 88:269

7. Colebatch HJ, Halamagyi DF 1963 Effect of vagotomy and vagal stimulation on lung mechanisms and circulation. J Appl Physiol 18:881

8. Corbet AJ, Flax P, Rudolph AJ 1976 Reduced surface tension in lung of fetal rabbits injected with pilocarpine. J Appl Physiol 41:7

9. El-Bermani I, Bloomquist EI 1978 Acetylcholinesterase and norepinephrine containing nerves in developing rat lung. J Embryol Exp Morphol 48:177

10. Giannopoulus $G 1980$ Identification and ontogeny of $\beta$-adrenergic receptors in fetal rabbit lung. Biochem Biophys Res Commun 95:388

11. Hancock AA, DeLean AL, Lefkowitz RJ 1979 Quantitative resolution of $\beta$ adrenergic subtypes by selective ligand binding: application of a computerized model fitting techniques. Mol Pharmacol 16:1

12. Hardin TK, Scheer AG, Smith MM 1982 Differential modification of the interaction of cardiac muscarinic cholinergic and beta-adrenergic receptors with a guanine nucleotide component. Mol Pharmacol 21:570

13. Lowry OH, Rosebrough NJ, Farr AL, Randall RJ 1951 Protein measurement with the Folin phenol reagent. J Biol Chem 193:265

14. Morikawa Y, Donahoe PK, Hendren WH 1978 Cholinergic nerve development in fetal lung. Dev Biol 65:541

15. Morikawa Y, Donohoe, PK, Hendren WH 1978 Cholinergic nerve development of fetal lung in vitro. $\mathrm{J}$ Ped Surg 13:653

16. Murlas C, Nadel JA, Roberts JM 1982 The muscarinic receptors of airway smooth muscle: their characteristics in vitro. J Appl Physiol 52:1084

17. Oyarzum MJ, Clements JA 1977 Control of lung surfactant by ventilation, adrenergic mediators and prostaglandins in the rabbit. J Appl Physiol 43:39

18. Rosenberger LB, Ploeske WR, Yamamura HI 1979 Regulation of muscarinic cholinergic receptors by guanine nucleotides in cardiac tissue. Eur J Pharmacol 56:179

19. Scatchard S 1949 The attractions of proteins for small molecules and ions. Ann NY Acad Sci 51:660

20. Whitsett JA, Darovec-Beckerman C, Adams K, Pollinger J, Needelman H 1980 Thyroid hormone mediates the development of pulmonary $\beta$-adrenergic receptors in the rat. Biochem Biophys Res Commun 97:913

21. Whitsett JA, Machulskis A, Noguchi A 1982 Ontogeny of $\alpha_{1}$-adrenergic receptors in rat lung. Life Sci 30:139

22. Whitsett JA, Manton MA, Darovec-Beckerman C, Adams KG, Moore JJ 1981 Development of $\beta$-adrenergic receptors in fetal rabbit lung. Am J Physiol 240:E351

23. Whitsett JA, Matz S, Darovec-Beckerman 1983 c-AMP dependent protein kinase and protein phosphorylation in developing rat lung. Pediatr Res 17:959

24. Yamamura HI, Snyder S 1974 Muscarinic cholinergic binding in rat brain. Proc Natl Acad Sci USA 71:1725 